\title{
Self-injury and suicide attempt in incarcerated women: prevalence and risk factors
}

\author{
Automutilação e tentativa de suicídio em mulheres encarceradas: prevalência e fatores de risco \\ Autolesiones e intento de suicidio en mujeres en situación de cárcel: prevalencia y factores de riesgo
}

Received: 05/05/2021 | Reviewed: 05/20/2021 | Accept: 05/31/2021 | Published: 06/14/2021

\author{
Eronyce Rayka de Oliveira Carvalho \\ ORCID: https://orcid.org/0000-0002-3868-3674 \\ Faculdade de Ciências Médicas da Santa Casa de São Paulo, Brazil \\ E-mail: eronycerayka@hotmail.com \\ Karla Santos Mateus \\ ORCID: https://orcid.org/0000-0001-5398-9578 \\ Universidade Federal da Paraíba, Brazil \\ E-mail: karlasmateus@gmail.com \\ Kaline da Silva Lima \\ ORCID: https://orcid.org/0000-0001-6127-5815 \\ Universidade Federal da Paraíba, Brazil \\ E-mail: kaline.s.lima@hotmail.com \\ Jeferson Barbosa Silva \\ ORCID: https://orcid.org/0000-0002-1083-1305 \\ Centro Universitário de João Pessoa, Brazil \\ E-mail: jefersonbarbosa_@hotmail.com \\ Ricardo Riyoiti Uchida \\ ORCID: https://orcid.org/0000-0002-4209-8830 \\ Faculdade de Ciências Médicas da Santa Casa de São Paulo, Brazil \\ E-mail: rruchida@uol.com.br
}

\begin{abstract}
Purpose: To assess the prevalence and risk factors for self-injury and suicide attempt in prison in a sample composed of 186 female inmates. Methods: Sociodemographic data, measures of depression, self-destructive behavior, suicide attempt, and other specific questions related to the reality in the prison environment were collected. Results: Self-injury and suicide attempt before incarceration was reported by $11.3 \%$ and $35.5 \%$ of the sample, respectively. During imprisonment, a prevalence of $29 \%$ and $18.8 \%$ for self-injury and suicide attempt, respectively, was observed. Multiple binary logistic regression identified the following risk factors for self-injury: age <32 years, depressive symptoms, history of torture at the time of the arrest, aggression in prison, and sexually transmitted infection. Conversely, the risk factors for suicide attempt were depressive symptoms, self-injury history, aggression in prison, and sexually transmitted infection. Conclusion: This study confirmed the high prevalence of self-harm and suicide attempts in female prisoners. Specific screening tools and the institution of public policies to assess and provide mental health care for incarcerated people in Brazil are needed.
\end{abstract}

Keywords: Self-injury; Suicide attempt; Women; Prison; Mental health.

\section{Resumo}

Objetivo: Avaliar a prevalência e os fatores de risco para automutilação e tentativa de suicídio na prisão em uma amostra composta por 186 presidiárias. Métodos: Foram coletados dados sociodemográficos, medidas de depressão, comportamento autodestrutivo, tentativa de suicídio e outras questões específicas relacionadas à realidade do ambiente prisional. Resultados: Automutilação e tentativa de suicídio antes do encarceramento foram relatados por 11,3\% e 35,5\% da amostra, respectivamente. Durante o aprisionamento, observou-se uma prevalência de $29 \%$ e 18,8\% de automutilação e tentativa de suicídio, respectivamente. A regressão logística binária múltipla identificou os seguintes fatores de risco para automutilação: idade $<32$ anos, sintomas depressivos, história de tortura no momento da prisão, agressão na prisão e infecção sexualmente transmissível. Por outro lado, os fatores de risco para tentativa de suicídio foram sintomas depressivos, história de automutilação, agressão na prisão e infecção sexualmente transmissível. Conclusão: Este estudo confirmou a alta prevalência de lesões autoprovocadas e tentativas de suicídio em presidiárias. São necessários instrumentos de triagem específicos e a implementação de políticas públicas voltadas para avaliação e cuidados em saúde mental para pessoas encarceradas no Brasil.

Palavras-chave: Automutilação; Tentativa de suicídio; Mulheres; Prisão; Saúde mental.

\section{Resumen}

Objetivo: Evaluar a partir de una muestra de 186 reclusos, la prevalencia y los factores de riesgo de la automutilación y del intento de suicidio en cárceles. Métodos: Se realizaron recolección de datos sociodemográficos, datos relativos a 
medidas de depresión, comportamiento autodestructivo, intento de suicidio y otras cuestiones específicas asociadas a la realidad del entorno carcelario. Resultados: La automutilación y el intento de suicidio antes del encarcelamiento emergen, respectivamente, en el 11,3\% y en el 35,5\% de la muestra. Durante la reclusión, se observa una prevalencia de $29 \%$ en los casos de autolesiones y del $18,8 \%$ en los de intentos de suicidio. Por medio de la regresión logística binaria múltiple, se identificaron como riesgos de automutilación los siguientes factores: la edad menor a 32 años, los antecedentes de tortura en el momento del arresto, los síntomas depresivos, las agresiones en la prisión y las infecciones de transmisión sexual. Por otro lado, los factores de riesgo asociados al intento de suicidio son los antecedentes de automutilación y, también, las agresiones en prisión y las infecciones de transmisión sexual. Conclusión: En este estudio se confirmó una alta prevalencia de autolesiones y de intentos de suicidio en mujeres en situación de cárcel. Así, concluimos que se necesitan instrumentos específicos de encarcelamiento y la implementación de políticas públicas orientadas a la evaluación y a la atención de la salud mental de personas en situación de cárcel en Brasil.

Palabras clave: Autolesión; Intento de suicídio; Mujeres; Prisión; Salud mental.

\section{Introduction}

The prevalence of psychiatric disorders in the prison population remains high, and reliable factors related to these disorders are still unknown (Baranyi G, 2019). Somehow, this fact may contribute to suicide as one of the leading causes of death in the prison environment, reaching $~ 50 \%$ of all deaths during incarceration (Fazel \& Baillargeon, 2011). Moreover, selfharm, suicide attempt, and suicide are also likely to occur in incarcerated women (Alemayehu, Ambaw, \& Gutema, 2019; Brazil, 2018; WHO, 2016). In 2003, the Brazilian government recognized the importance of conducting epidemiological studies in the prison population (Brazil, 2003) since it comprises the third-largest prison population worldwide; however, studies on this topic are still scarce.

Despite the strong association between non-suicidal self-injury and suicide attempts, both must be considered differently. Conceptually, self-injury is an intentional behavior that involves direct aggression to the body itself without suicidal intent (Favazza, 1998). Superficial cuts, burns, scratches, self-biting, self-punching, and picking at wounds are the most common types of self-injury behavior (Favazza, 1998). According to the American Psychiatric Association (Association, 2013), this behavioral syndrome is present in various diagnostic contexts and is associated with interpersonal difficulties, feelings, or negative thoughts. The expectation of people who engage in this intentional self-inflicted harm is that the injury will only lead to minor or moderate physical harm (i.e., getting relief from a negative feeling or cognition), solve an interpersonal difficulty, or induce positive feelings. Conversely, when suicide is attempted, the intention to die is considered, as well as the violence of the method, the medical consequences, and both the degree of planning and impulsiveness (Association, 2013). In brief, while self-injury constitutes an inadequate way of dealing with conflicts, the suicide attempt is intended to end life. In this sense, it is essential to classify these behaviors differently since a minor mistake may lead to unnecessary hospitalization and misallocation of valuable emergency resources.

According to the World Health Organization (WHO, 2002), both self-injury behavior and suicide attempt are situated in one of the three types of violence: self-directed, collective, and interpersonal violence. Vulnerable social groups (e.g., women/prisoners) present high suicidal behavior rates (Brazil, 2017; WHO, 2016), mainly in developing countries (WHO, 2019). Furthermore, several studies demonstrated a strong relationship between self-injury and suicide, regardless of social status. Although the most important risk factor for predicting suicide is suicide attempt (Taron, Nunes, \& Maia, 2020), a study performed by Klonsky, May, and Glenn (2013) pointed the possibility of self-injury as an important risk factor for suicide, probably because the repetition of self-injurious behaviors may lead to desensitization and encourage the individual to commit lethal injuries (Favazza \& Conterio, 1989). This behavior can be aggravated in the prison environment due to the various factors affecting the prisoners' mental health. Indeed, the incidence of self-injury in incarcerated women is significantly high worldwide (Völlm \& Dolan, 2009), while this population is 20-fold more likely to commit suicide than non-incarcerated women in Brazil (Alemayehu, et al., 2019). 
The repressive social control of the prison system (Brazil, 2005; Espinoza, 2004; Goffman., 1961; Soares, 2002; Wacquant, 2008) makes this environment unhealthy to live (Carraro, 2014) and causes stress, sadness, and helplessness. Consequently, self-injury is mainly caused by the lack of alternatives to face emotional problems. This inadequate coping produces momentary gratification and relief that acts as a strong behavioral reinforcement (Winicov, 2019). Other factors related to self-directed violence in prison are clinical (family history of suicide, aggressive and impulsive behavior, depression, medication use, mental health problems in prison, and suicide attempts), psychosocial (lack of social and family support, stressful and traumatic life events, history of sexual abuse, and lack of ability to cope with adverse situations), and institutional (overcrowding, isolation, harassment, deprivation, and disciplinary measures) (Barker, Kõlves, \& De Leo, 2014; Hawton, Linsell, Adeniji, Sariaslan, \& Fazel, 2014; Knight, Coid, \& Ullrich, 2017). Nevertheless, most of the studies performed with incarcerated women were conducted in developed countries, which may differ from other countries due to cultural and socioeconomic conditions. Thus, this study aims to assess the prevalence and factors associated with self-injury and suicide attempt in incarcerated women.

\section{Methodology}

\subsection{About the study}

This is a cross-sectional, descriptive and correlational study of quantitative approach.Thus, this research aimed to specify properties and important characteristics of a group (incarcerated women) through data collection and verified the association between variables (see Sampieri et al., 2013).

\subsection{Participants}

This is a cross-sectional study conducted with women in closed regime at the penitentiary with the highest population density in the state of Paraíba/Brazil (Maria Júlia Maranhão Penitentiary), located in the city of João Pessoa. Data collection was carried out from July 2019 to March 2020, and all women in preventive detention or sentenced to a closed regime were eligible to participate in the study. Those who did not have the cognitive ability to answer the instruments were excluded.

The prison unit has a mean daily occupation of 200 prisoners, and this number is changed daily with the entry and exit of inmates. Thus, data collection was conducted in each cell separately without turning back to the already evaluated cell. Of the eligible inmates, some left prison before evaluation due to license, parole, house arrest, or regime progression (we do not have information on the quantity). Six refused to participate in the study, and one was excluded due to cognitive issues during the application of the instruments.

\subsection{Procedures and ethical approval}

The study was authorized by the State Penitentiary Administration, approved by the research ethics committee of the Federal University of Paraíba ( $n^{\circ} 3.475 .273$ ), and conducted within the confines of the Declaration of Helsinki. All participants signed an informed consent form and were informed that their collaboration was voluntary and anonymous.

After signing the informed consent form, a structured individual interview was conducted in the psychological care room of the prison. Each interview lasted $\sim 60$ minutes, and the researcher filled out the answers for all instruments due to the high rate of illiteracy. 


\subsection{Measures}

Sociodemographic, clinical, and juridical profiles - Before applying the questionnaires, data regarding age, income, color/race, sexual orientation, marital status and relationships in prison, children, religion, disease (hypertension, diabetes, and sexually transmitted infection), sexual orientation, mental health (history of family suicide, depression, mental disorder, psychiatric drug use, alcohol, and illicit drugs), history of violence (aggression and torture at the time of arrest or in prison, and rape), and imprisonment/criminal situation were collected. Right after, the number of suicide attempts before and after the arrest and the time from the last suicide attempt were verified using direct questions.

Functional Assessment of Self-Mutilation (FASM) (Lloyd-Richardson, 1997) - This instrument investigates the methods, frequencies, and reasons for self-mutilation. The scale addresses the occurrence of 11 different types of self-injury behaviors (i.e., cutting the skin, burning the skin, self-biting, scratching the skin, inserting objects to the nail or skin, self-punching, picking at the wound, pulling hair, erasing the skin, and self-tattooing) during the last year and the degree of physical pain during selfmutilation. The latter is rated on a 4-point Likert scale ranging from "painless" to "severe pain". In our study, the self-injury methods before and during the imprisonment were also assessed. The motivating aspects were assessed using a list of 23 items, also rated on a 4-point Likert scale ranging from "never" to "often".

Patient health questionnaire (PHQ9) - This instrument comprises nine questions assessing the presence of major depression symptoms in the previous 14 days, as described in the Diagnostic and Statistical Manual of Mental Disorders (DSMIV). The items are scored on a scale from 0 to 3 , and the total score ranges from 0 to 27 . The sum of the nine items corresponds to the following descriptions: 0-4 points (no depression); 5-9 points (mild depressive disorder); 10-14 points (moderate depressive disorder); 15-19 points (moderately severe depressive disorder), and 20 to 27 points (severe depressive disorder) (Kroenke, Spitzer, \& Williams, 2001). For data analysis, the participants were classified as no depressive disorders (participants who scored 0-9 points) and depressive disorders (scores $>9$ points), which, in a validation study with an adult population in southern Brazil, revealed a sensitivity of $72.5 \%$ (95\% CI: $61.5 \%$ to $89.2 \%$ ) and specificity of $88.9 \%$ (95\% CI: $83.0 \%$ to $89.9 \%$ ) (Santos, et al., 2013).

\subsection{Data analysis}

To analyze the data, we used the SPSS software (Statistical Package for the Social Sciences), version 22.0, a tool for statistical analysis. This program made it possible to obtain data frequencies, as well as averages. Association measures were performed in contingency tables and Fisher's Exact test, and the multiple binary logistic regression model was also used, the backward method was applied, which included all variables that showed significant differences in the referred associations. The decision to remove the variable was made based on partial $\mathrm{F}$ tests. The results were presented in tables, charts and graphs and discussed based on the thematic literature. The level of statistical significance adopted was equal to $5 \%$, that is, the results of the statistical tests were considered statistically significant when $\mathrm{p}<0.05$.

\section{Results}

\subsection{Statistical analysis}

Data are shown as mean \pm standard deviation and $95 \%$ confidence interval. Associations between self-injury in prison and sociodemographic, clinical, juridical profile, history of violence, and mental health status data were performed using contingency tables and Pearson's Chi-Square test. The variables significantly associated with self-injury were included in a multivariate binary logistic regression (applying the backward method) to assess the predictors of self-injury and suicide attempt in prison. In each model, the Nagelkerke $\mathrm{R}^{2}$ was used to measure the goodness of fit. The decision to remove the variable from 
the model was based on partial $\mathrm{F}$ tests, being considered significant when $\mathrm{p}<0.05$. Inferential analyses were conducted using SPSS statistical software version 22.0. (IBM Corp., USA).

\subsection{Subject characteristics}

Two hundred and seven incarcerated women were recruited, but only 186 (mean age of 33.4 \pm 9.8 ) were included. Six refused to participate in the study, and one was excluded due to cognitive issues during the application of the instruments. More than two-thirds of the sample (67.2\%) declared themselves black/brown, 32.3\% white, and 0.5\% indigenous. Regarding religion, 45.7\% were Catholic, $39.2 \%$ Protestant, $1.6 \%$ Spiritist, and $13.4 \%$ declared no religion. More than half of the sample (72.6\%) was single, while $12.9 \%$ were in a stable relationship. Regarding sexual orientation, $60.8 \%$ claimed to be heterosexual, $11.8 \%$ homosexual, and $27.4 \%$ bisexual. Elementary school was not finished by $67.2 \%$ of the sample, while only $1.6 \%$ finished higher education. Eighty-one women (45.6\%) had paid work before prison, but only four (4.9\%) had formal work. The mean monthly family income of the sample was $\mathrm{R} \$ 1.588,00$ reais, while the mean monthly per capita income was $\mathrm{R} \$ 434,00$ reais. Seventytwo participants (38.7\%) received monthly assistance benefits ( $\mathrm{R} \$ 205,00$ reais) from the federal government.

\subsection{Mental health}

Self-injury before of the prison was reported by $11.3 \%$ of the sample $(\mathrm{n}=21)$, while 54 women (29\%) committed selfinjury in prison and $59(31.7 \%)$ throughout their lifetime. Self-punching $(71.4 \%)$ and cutting the skin $(52.4 \%)$ were the most common types of self-injury during freedom while cutting the skin (77.8\%), self-punching (53.7\%), and scratching the skin $(51.8 \%)$ were the most frequent methods during incarceration. It was also observed that $80 \%$ of participants with a history of self-injury did not feel pain, and $10 \%$ used to feel less pain. Moreover, several motivations for engaging in self-destructive behaviors were observed, such as stop bad feelings or sensations (71.7\%), feel relaxed (40\%), and relieve feelings of emptiness or indifference (31.7\%). Suicide was attempted by $35.5 \%(\mathrm{n}=66)$ before arrest, while $18.8 \%(\mathrm{n}=35)$ tried it during incarceration. Depressive symptoms were observed in $147(55,4 \%)$ participants.

\subsection{Associations with self-injury in prison}

Self-injury and suicide attempt in prison were reported by 24 women (12.9\%). Of these, 23 (95.8\%) reported performing the self-injury first. As shown in Table 1, self-injury in prison was associated with suicide attempt in prison ( $\mathrm{p}<0.001)$, age $<32$ years $(\mathrm{p}=0.001)$, amorous relationships with another prisoner $(\mathrm{p}<0.001)$, depression $(\mathrm{p}<0.001)$, history of mental disorder ( $\mathrm{p}<0.001)$, use of psychiatric drugs ( $\mathrm{p}<0.001)$, history of suicide attempt ( $\mathrm{p}=0.003)$, use of illicit drugs ( $\mathrm{p}=0.001)$, aggression at the time of arrest $(\mathrm{p}<0.001)$, torture at the time of arrest $(\mathrm{p}<0.001)$, physical aggressions in prison $(\mathrm{p}<0.001)$, deprivation time $(\mathrm{p}=0.003)$, being sentenced $(\mathrm{p}<0.001)$, and sexually transmitted infection identification $(\mathrm{p}=0.002)$. 
Table 1 - Associations (Pearson's Chi-Square test) between self-injury in prison and sociodemographic and clinical data, juridical profile, history of violence, and mental health status.

\begin{tabular}{|c|c|c|c|c|c|}
\hline \multirow[b]{2}{*}{ Variable } & \multicolumn{3}{|c|}{ Self-injury in prison } & \multirow[b]{2}{*}{$p$-value } & \multirow[b]{2}{*}{ OR (CI 95\%) } \\
\hline & $\begin{array}{c}\text { Total sample } \\
(\mathbf{N}=\mathbf{1 8 6})\end{array}$ & $\begin{array}{c}\text { No } \\
(\mathbf{N}=132)\end{array}$ & $\begin{array}{c}\text { Yes } \\
(\mathrm{N}=54)\end{array}$ & & \\
\hline \multicolumn{6}{|l|}{ Age } \\
\hline$<32$ years & $95(51.1 \%)$ & $57(43.2 \%)$ & $38(70.4 \%)$ & \multirow{2}{*}{0.001} & $2.27(1.36 ; 3.78)$ \\
\hline$>32$ years & $91(48.9 \%)$ & $75(56.8 \%)$ & $16(29.6 \%)$ & & \\
\hline \multicolumn{6}{|l|}{ Race/Color } \\
\hline Black/Brown & $125(67.2 \%)$ & $88(66.7 \%)$ & $37(68.5 \%)$ & \multirow{3}{*}{0.801} & - \\
\hline White & $60(32.3 \%)$ & $43(32.6 \%)$ & $17(31.5 \%)$ & & \\
\hline Indigenous & $1(0.5 \%)$ & $1(0.8 \%)$ & $0(0.0 \%)$ & & \\
\hline Children (Yes) & $158(84.9 \%)$ & $113(85.6 \%)$ & $45(83.3 \%)$ & 0.694 & $0.86(0.49 ; 1.60)$ \\
\hline Visit (Yes) & $95(51.1 \%)$ & $66(50.0 \%)$ & $29(53.7 \%)$ & 0.646 & $1.16(0.61 ; 2.18)$ \\
\hline Intimate visit (No) & $181(97.3 \%)$ & $127(96.2 \%)$ & $54(100 \%)$ & 0.147 & $1.42(1.29 ; 1.56)$ \\
\hline $\begin{array}{l}\text { Amorous relationship with another } \\
\text { prisoner (Yes) }\end{array}$ & $48(25.8 \%)$ & $23(17.4 \%)$ & $25(46.3 \%)$ & $<0.001$ & $2.47(1.62 ; 3.78)$ \\
\hline \multicolumn{6}{|l|}{ Clinical mental health data } \\
\hline History of family suicide (Yes) & $22(11.8 \%)$ & $13(9.8 \%)$ & $9(16.7 \%)$ & 0.191 & $0.54(0.21 ; 1.36)$ \\
\hline Depression (Yes) & $103(55.4 \%)$ & $56(42.4 \%)$ & $47(87.0 \%)$ & $<0.001$ & $9.11(3.83 ; 21.66)$ \\
\hline Mental disorder (Yes) & $66(35.5 \%)$ & $36(27.3 \%)$ & $30(55.6 \%)$ & $<0.001$ & $3.33(1.72 ; 6.44)$ \\
\hline Psychiatric drug use (Yes) & $53(28.5 \%)$ & $23(17.4 \%)$ & $30(55.6 \%)$ & $<0.001$ & \\
\hline Psychological monitoring (Yes) & $83(44.6 \%)$ & $44(33.3 \%)$ & $39(72.2 \%)$ & $<0.001$ & $3.22(1.91 ; 5.43)$ \\
\hline Suicide attempt before the arrest (Yes) & $66(35.5 \%)$ & $38(28.8 \%)$ & $28(51.9 \%)$ & 0.003 & $2.66(1.36 ; 5.12)$ \\
\hline Suicide attempt inside prison (Yes) & $35(18.8 \%)$ & $11(8.3 \%)$ & $24(44.4 \%)$ & $<0.001$ & $8.80(3.88 ; 19.94)$ \\
\hline Sleep well (Yes) & $80(43 \%)$ & $60(45.5 \%)$ & $20(37.0 \%)$ & 0.293 & $1.41(0.74 ; 2.71)$ \\
\hline Alcohol (Yes) & $56(30.1 \%)$ & $42(31.8 \%)$ & $14(25.9 \%)$ & 0.427 & $0.75(0.36 ; 1.52)$ \\
\hline Illicit Drugs (Yes) & $122(65.6 \%)$ & $77(58.3 \%)$ & $45(83.3 \%)$ & 0.001 & $3.57(1.61 ; 7.90)$ \\
\hline \multicolumn{6}{|l|}{ History of Violence } \\
\hline Lost the child (Yes) & $30(16.1 \%)$ & $24(18.2 \%)$ & $6(11.1 \%)$ & 0.234 & $1.77(0.68 ; 4.62)$ \\
\hline Aggression at the time of arrest (Yes) & $56(30.1 \%)$ & $29(22.0 \%)$ & $27(50.0 \%)$ & $<0.001$ & $2.32(1.50 ; 3.57)$ \\
\hline Torture at the time of arrest (Yes) & $35(18.8 \%)$ & $16(12.1 \%)$ & $19(35.2 \%)$ & $<0.001$ & $2.34(1.53 ; 3.56)$ \\
\hline Physical aggressions in prison (Yes) & $23(12.4 \%)$ & $9(6.8 \%)$ & $14(25.9 \%)$ & $<0.001$ & $2.48(1.62 ; 3.79)$ \\
\hline Aggressions in freedom (Yes) & $104(55.9 \%)$ & $69(52.3 \%)$ & $35(64.8 \%)$ & 0.118 & $0.59(0.30 ; 1.14)$ \\
\hline Rape (Yes) & $49(26.3 \%)$ & $30(22.7 \%)$ & $19(35.2 \%)$ & 0.080 & $1.84(0.92 ; 3.68)$ \\
\hline Other abuse (Yes) & $60(32.3 \%)$ & $39(29.5 \%)$ & $21(38.9 \%)$ & 0.216 & $1.51(0.78 ; 2.94)$ \\
\hline \multicolumn{6}{|l|}{ Criminal Situation } \\
\hline \multicolumn{6}{|l|}{ Deprivation Time } \\
\hline$>12$ months & $89(47.8 \%)$ & $54(40.9 \%)$ & $35(64.8 \%)$ & \multirow{2}{*}{0.003} & \multirow[t]{2}{*}{$2.66(1.37 ; 5.13)$} \\
\hline$<12$ months & $97(52.2 \%)$ & $78(59.1 \%)$ & $19(35.2 \%)$ & & \\
\hline Recurrence (Yes) & $78(41.9 \%)$ & $53(40.2 \%)$ & $19(46.3 \%)$ & 0.441 & $1.28(0.67 ; 2.43)$ \\
\hline Sentenced (Yes) & $106(57.0 \%)$ & $64(48.5 \%)$ & $42(77.8 \%)$ & $<0.001$ & $2.64(1.49 ; 4.68)$ \\
\hline Religious accompaniment (Yes) & $113(60.8 \%)$ & $80(60.6 \%)$ & $33(61.1 \%)$ & 0.949 & $1.02(0.53 ; 1.95)$ \\
\hline \multicolumn{6}{|l|}{ Clinical Data } \\
\hline Hypertension (Yes) & $25(13.4 \%$ & $20(15.2 \%)$ & $5(9.3 \%)$ & 0.285 & $0.57(0.20 ; 1.61)$ \\
\hline Diabetes (Yes) & $5(2.7 \%)$ & $4(3.0 \%)$ & $1(1.9 \%)$ & 0.652 & $0.60(0.06 ; 5.52)$ \\
\hline Sexually transmitted infection (Yes) & $23(12.4 \%)$ & $10(7.6 \%)$ & $13(24.1 \%)$ & 0.002 & $3.86(1.57 ; 9.48)$ \\
\hline
\end{tabular}

OR $($ CI 95\%) = Odds Ratio (95\% confidence interval) of each variable separately.

Fonte: Autores (2021). 


\subsection{Backward multiple binary logistic regressions}

The model built for self-injury $\left(\mathrm{R}^{2}\right.$ Nagelkerke $\left.=0.47\right)$ showed that age $>32$ years significantly reduces the chances of selfinjury, while each increase the risk of self-injury: depression score by 1.15 times; the presence of torture at the time of arrest increase by 5.34 times; physical aggressions in prison by 4.09 times; and sexually transmitted infection identification by 4.66 times. The rate for predicting self-injury in the final model was $82.8 \%$ (Table 2).

Conversely, suicide attempts in prison were significantly associated $\left(\mathrm{R}^{2}\right.$ Nagelkerke $\left.=0.40\right)$ with depression score (risk increase of 1.17 times), self-injury in prison (risk increase of 3.03 times), physical aggressions in prison (risk increase of 3.94 times), and identification of sexually transmitted infection (risk increase of 4.64 times) as we can see in the Table 3 . The rate for predicting suicide attempt in the final model was $86.0 \%$.

Table 2 - Predictors of self-injury in prison.

\begin{tabular}{|c|c|c|c|c|c|c|}
\hline \multirow[b]{2}{*}{ Variable } & & \multirow[b]{2}{*}{$\beta$} & \multirow[b]{2}{*}{$\mathbf{O R}$} & \multicolumn{2}{|c|}{$95 \% \mathrm{CI}$} & \multirow[b]{2}{*}{ p-value } \\
\hline & & & & Lower & Upper & \\
\hline Age & (>32 years) & -1.04 & 0.35 & 0.14 & 0.86 & 0.022 \\
\hline Depression & Yes & 0.16 & 1.17 & 1.09 & 1.27 & $<0.001$ \\
\hline Torture at the time of arrest (yes) & Yes & 1.67 & 5.34 & 1.94 & 14.73 & 0.001 \\
\hline physical aggressions in prison & Yes & 1.40 & 4.09 & 1.21 & 13.78 & 0.023 \\
\hline sexually transmitted infection & Yes & 1.54 & 4.66 & 1.44 & 15.06 & 0.010 \\
\hline
\end{tabular}

$\beta$ : Regression coefficient; OR: Odds Ratio; 95\% CI: 95\% Confidence Interval.

Fonte: Autores (2021).

Table 3 - Predictors of suicide in prison.

\begin{tabular}{lcccccc}
\hline & & & & \multicolumn{2}{c}{ 95\% CI } \\
\cline { 4 - 6 } Variable & & $\boldsymbol{\beta}$ & OR & Lower & Upper & p-value \\
\hline Depression & Yes & 0.16 & 1.17 & 1.07 & 1.28 & 0.001 \\
Self-injury & Yes & 0.11 & 3.03 & 1.20 & 7.65 & 0.018 \\
Physical aggressions in prison & Yes & 1.37 & 3.94 & 1.25 & 12.44 & 0.019 \\
Identification of sexually transmitted infection & Yes & 1.53 & 4.64 & 1.47 & 14.62 & 0.009 \\
\hline
\end{tabular}

$\beta$ : Regression coefficient; OR: Odds Ratio; 95\% CI: 95\% Confidence Interval.

Fonte: Autores (2021).

\section{Discussion}

The main findings of this study were that women aging <32 years, with depressive symptoms, history of physical aggression from other inmates, identification of sexually transmitted infections and history of torture at the time of arrest present a greater risk of self-injury in prison, while the presence of depressive symptoms, history of self-injury in prison, history of physical aggression from other inmates, and identification of sexually transmitted infections increase the chances of attempting suicide in this environment. Also, the results indicate that self-injury and suicide attempt are frequent behaviors among incarcerated women.

The profile of women in a closed regime in the prison unit was similar to other prisons in Brazil and is mainly related to social exclusion, which is considered a risk factor for self-aggressive behaviors in Brazilian women (Brazil, 2017).

Self-injury before the arrest was reported by 21 (11.3\%) women, and its prevalence during incarceration was $29 \%$, suggesting that previous similar behaviors may influence self-injury in prison (Hawton, et al., 2014). Conversely, the prevalence of suicide attempts during prison dropped $46.9 \%(n=31)$ compared with the period before incarceration. This may be related to the restrictive and controlled prison environment or simply to the fact that the incarceration time is lower than the lifetime outside prison. Another possible explanation is related to a State Law (number 10,327/2014) that grants the prison staff if no violent 
deaths (i.e., homicides and suicides) occur in prison. This may lead to vigilance increase over inmates presenting signs of suicidal ideation or behavior and agreements between prison staff and inmates. Indeed, no suicides were reported in female prisons in the state of Paraíba in 2016 compared with other Brazilian prisons (2.8 suicides for every 10,000 women arrested) (Alemayehu, et al., 2019). The last suicide in the studied prison unit occurred in 2012, probably reflecting the mentioned state law. Nevertheless, self-injury is not a topic that receives greater attention, mainly because this behavior can be hidden. Thus, we believe the lack of discussion regarding self-injury in the Brazilian scenario is reflected in the prison system.

From 2011 to 2016, 176,226 cases of self-injury and suicide attempt were reported in the general Brazilian population, with women being responsible for $65.9 \%$ and 69\%, respectively (Brazil, 2017). Although these rates are high, there is no concrete data regarding female prisoners in Brazil. This data absence (or omission) prevents the creation of interventions and public policies for this vulnerable social group; therefore, it is essential to identify and notify the violence in this population. Another possibility would be creating an electronic form for the notification of self-directed violence in the prison system.

To our knowledge, this is the first study presenting epidemiological data regarding self-injury and suicide attempts in Brazilian incarcerated women. The prevalence of lifetime self-injury observed was $31 \%$, which is similar to the United Kingdom (27.9\%) (Völlm \& Dolan, 2009) but different from Canada (38\%) (Power, Brown, \& Usher, 2013) and England (58.4\%) (Haw, Hawton, Houston, \& Townsend, 2001). Regarding self-injury in prison, a prevalence rate of $29 \%$ was found, which is higher than in Canada (15.3\%) (Power, et al., 2013) and Israel (0.7\%) (Vinokur \& Levine, 2019), and can be explained by differences in culture, the prison system, and health policies. When considering self-injury before incarceration, a prevalence rate of $11 \%$ was observed, which is 5-fold lower than the prevalence observed in Canada (59.6\%) (Power, et al., 2013). However, the different assessment methods and the reality of different prisons preclude the possibility of comparing our data to data derived from other countries. For example, an exclusive system for assisting prisoners at risk of suicide and self-injury is present in prisons in England and Wales, which may interfere with the comparison between prevalence rates (Hawton, et al., 2014; Marzano, Fazel, Rivlin, \& Hawton, 2010). Also, studies regarding this topic were mostly performed in developed countries whose socio-economic and cultural factors may not reflect the reality of developing countries (Barker, et al., 2014; Hawton, et al., 2014; Knight, et al., 2017; Marzano, et al., 2010; Power, et al., 2013; Völlm \& Dolan, 2009).

The most frequent self-injury methods in prison corroborate with other studies (Hawton, et al., 2014; Power, et al., 2013). According to Garreto (2015), cutting the skin is one of the most severe forms of self-injury, and the fact that $80 \%$ of the participants with a history of self-injury did not feel pain during self-injury can cause a lethal practice without the conscious intention of suicide (Favazza \& Conterio, 1989). The motivation for self-injury in prison was also consistent with other studies (Völlm \& Dolan, 2009), thus confirming that it is practiced to reduce emotional pain (Association, 2013).

The high prevalence of depression in our study also corroborated with others (Haw, et al., 2001; Marzano, et al., 2010) and was considered an important risk factor for self-injury and suicide attempt in prison. Suffering physical aggression from other inmates was also a strong predictor of self-mutilation and suicide attempt in prison. This can be explained by the unstable environment and the difficulty of maintaining a peaceful coexistence in a space involving power relations, rivalry, oppression, and threats. Therefore, the inability to manage these potential stressors may lead to self-mutilation and suicide attempt as a problem-solving method (Enggist, 2014). The model also identified sexually transmitted infections as risk factors for selfmutilation and suicide attempt in the prison environment, probably due to the negative feelings generated following diagnosis at prison arrival and its acceptance. Studies suggest that the relationship between HIV diagnosis and suicidal ideation in prison is stronger than observed in clinical settings (Peng, et al., 2010). Our results showed that young women (age <32 years) are at high risk for self-harm behaviors (Hawton, et al., 2014), while torture at the time of arrest is a risk factor that may reflect the impulsive/aggressive behaviors (Hawton, et al., 2014; Vinokur \& Levine, 2019) commonly present in this group. Self-injury may be considered an emotional regulation strategy to manage negative feelings (Völlm \& Dolan, 2009) in the face of police 
repression and the lack of opportunity to externalize these behaviors; however, this topic requires further investigation. Furthermore, self-mutilation was identified in this study as a risk factor for suicide attempt in prison (24 women have self-harmed and attempted suicide); of these, $95.8 \%$ reported self-mutilation first, indicating that this behavior in prison can evolve to a suicide attempt.

In our study, clinical mental health variables (i.e., history of mental disorder, use of psychotropic drugs, history of suicide attempt, and history of illicit drug use) were significantly associated with self-injury in prison; however, these associations were not included in the final multiple model (Barker, et al., 2014; Hawton, et al., 2014; Knight, et al., 2017). An association with amorous relationship inside the prison was also found, and, in our experience, this fact is related to the instability in maintaining a healthy relationship since jealousy, emotional dependence, and confusion are very common in this environment, thus being a potential stress enhancer for dysfunctional coping strategies, such as self-injury (Winicov, 2019). Regarding deprivation time, it seems that the longer the confinement time, the greater the vulnerability to prison stressors and the witness of self-destructive behaviors, thus increasing the chances of reproducing the behavior. The deprivation time may also explain why a prison sentence was associated with self-injury.

This study is not free of limitations. Despite the relatively small sample size, the results are valuable to the literature since it highlights the presence of self-injury and suicide attempt in incarcerated women and discusses the importance of this problem in the prison system. Also, the lack of specific measures to assess the prisoner's self-directed violence may have hindered more precise risk factors identification. Thus, further studies are needed to develop novel instruments for this socially neglected population. Another limitation refers to the importance of diagnosing psychiatric disorders. The participants of this study did not receive any diagnosis since only one measure for depressive disorders was used, thus precluding other important factors, such as personality disorders (Marzano, et al., 2010). These limitations must be overcome in larger longitudinal studies to ensure the psychological integrity of the participants.

\section{Final Considerations}

Self-injury and suicide attempt are frequent behaviors in incarcerated women in Brazil. Age, depressive symptoms, and torture at the time of arrest are essential factors associated with self-injury, while suicide attempt is influenced by depressive symptoms, history of self-injury in prison, history of physical aggression from other inmates, and identification of sexually transmitted infections. These results contribute to highlight the suffering that is relatively hidden, since people tend to hide this behavior (self-injury), especially in a population that is socially invisible (Hatje, 2015). Despite this notorious contribution, the study in question has some limitations, which does not reduce its importance, but indicates the need to study more broadly the themes addressed here. Thus, we highlight the need to create specific psychometric instruments for the incarcerated population to insert screening, in order to identify people more prone to self-destructive behaviors. We also consider it important to conduct studies with other samples of people in deprivation of liberty, such as men and adolescents and the development of public policies to provide mental health in the prison system.

\section{References}

Alemayehu, F., Ambaw, F., \& Gutema, H. (2019). Depression and associated factors among prisoners in Bahir Dar Prison, Ethiopia. $19,88$.

Association, A. P. (2013). Diagnostic and Statistical Manual of Mental Disorders (DSM-V) (5a ed.).

Baranyi, G. S. C., Fazel, S., Patel, V., Priebe, S., \& Mundt, A. (2019). Severe mental illness and substance use disorders in prisoners in low-income and middleincome countries: A systematic review and meta-analysis of prevalence studies. The Lancet, 7, 461-471.

Barker, E., Kõlves, K., \& De Leo, D. (2014). Management of suicidal and self-harming behaviors in prisons: systematic literature review of evidence-based activities. Arch Suicide Res, 18, 227-240. 
Brazil. (2003). Portaria Interministerial nº 1777/MS/MJ. Plano Nacional de Saúde no Sistema Penitenciário. In (Vol. 2020): Ministério da Saúde.

Brazil. (2005). Plano Nacional de Saúde no Sistema Penitenciário. In (Vol. 2019): Ministério da Saúde. Secretaria de Atenção à Saúde. Departamento de Ações Programáticas Estratégicas. .

Brazil. (2017). Perfil epidemiológico das tentativas e óbitos por suicídio no Brasil e a rede de atenção à saúde. Secretaria de Vigilância em Saúde - Ministério da Saúde.

Brazil. (2018). Departamento Penitenciário Nacional. Levantamento Nacional de Informações Penitenciárias. In (2nd ed.), Infopen Mulheres - Ministério da Justiça. .

Carraro, E. (2014). O princípio da dignidade da pessoa humana e o preso portador de deficiência física: rumo à adequação física dos estabelecimentos prisionais. Revista da Escola Superior da Magistratura do Estado de Santa Catarina, 21, 399-424.

Enggist, S. M., L.; Galea, G.; \& Udese, C. (2014). Prison and Health. In (Vol. 2020).

Espinoza, O. (2004). A mulher encarcerada em face do poder punitivo. IBCCRIM.

Favazza, A. R. (1998). The coming of age of self-mutilation. J Nerv Ment Dis, 186, 259-268.

Favazza, A. R., \& Conterio, K. (1989). Female habitual self-mutilators. Acta Psychiatr Scand, 79, 283-289.

Fazel, S., \& Baillargeon, J. (2011). The health of prisoners. Lancet, 377, 956-965.

Garreto, A. K. R. (2015). O desempenho executivo em pacientes que apresentam automutilação. Faculdade de Medicina da Universidade de São Paulo.

Goffman. (1961). Manicômios, prisões e conventos. Editora Perspectiva.

Hatje, L. F. (2015). Gênero e prisão: a invisibilidade da mulher no sistema penitenciário-perspectivas com a construção do presídio feminino regionalizado do Rio Grande/RS (Bachelor's thesis).

Haw, C., Hawton, K., Houston, K., \& Townsend, E. (2001). Psychiatric and personality disorders in deliberate self-harm patients. Br J Psychiatry, 178 , 48-54.

Hawton, K., Linsell, L., Adeniji, T., Sariaslan, A., \& Fazel, S. (2014). Self-harm in prisons in England and Wales: an epidemiological study of prevalence, risk factors, clustering, and subsequent suicide. Lancet, 383, 1147-1154.

Klonsky, E. D., May, A. M., \& Glenn, C. R. (2013). The relationship between nonsuicidal self-injury and attempted suicide: converging evidence from four samples. 122, 231-237.

Knight, B., Coid, J., \& Ullrich, S. (2017). Non-Suicidal Self-Injury in UK Prisoners. International Journal of Forensic Mental Health, 16, $172-182$.

Kroenke, K., Spitzer, R. L., \& Williams, J. B. (2001). The PHQ-9: validity of a brief depression severity measure. J Gen Intern Med, 16, 606-613.

Lloyd-Richardson EE, K. M., Hope T. (1997). Self-mutilation in a community sample of adolescents. Louisiana State University, Louisiana.

Marzano, L., Fazel, S., Rivlin, A., \& Hawton, K. (2010). Psychiatric disorders in women prisoners who have engaged in near-lethal self-harm: case-control study. Br J Psychiatry, 197, 219-226.

Peng, E. Y.-C., Yeh, C.-Y., Lyu, S.-Y., Morisky, D. E., Chen, Y.-M. A., Lee, M.-B., Farabee, D., \& Malow, R. M. (2010). Prevalence and correlates of lifetime suicidal ideation among HIV-infected male inmates in Taiwan. AIDS Care, 22, 1212-1220.

Power, J., Brown, S. L., \& Usher, A. M. (2013). Prevalence and Incidence of Nonsuicidal Self-Injury Among Federally Sentenced Women in Canada. Criminal Justice and Behavior, 40, 302-320.

Sampieri, R. H., Collado, C. F., \& Lucio, M. D. P. B. Metodologia de Pesquisa. Tradução de Daisy Vaz de Moraes. (5a ed.), Penso; 2013.

Santos, I. S., Tavares, B. F., Munhoz, T. N., Almeida, L. S. P., Silva, N. T. B., Tams, B. D., Patella, A. M., \& Matijasevich, A. (2013). Sensibilidade e especificidade do Patient Health Questionnaire-9 (PHQ-9) entre adultos da população geral. Cad Saude Publica, 29(8), 1533-43.

Soares, B. I.. I. (2002). Prisioneiras: Vida e violência atrás das grades. Garamond.

Taron, M., Nunes, C., \& Maia, T. (2020). Suicide and suicide attempts in adults: exploring suicide risk 24 months after a psychiatric emergency room visit. Braz J Psychiatry, 42, 367-371.

Vinokur, D., \& Levine, S. Z. (2019). Non-suicidal self-harm in prison: A national population-based study. Psychiatry Res, 272, $216-221$.

Völlm, B. A., \& Dolan, M. C. (2009). Self-harm among UK female prisoners: a cross-sectional study. The Journal of Forensic Psychiatry \& Psychology, 20, 741-751.

Wacquant, L. (2008). O lugar da prisão na nova administração da pobreza. In (Vol. 2020): Novos estud. - CEBRAP.

WHO. (2002). World report on violence and health. World Health Organization.

WHO. (2016). Practice manual for establishing and maintaining surveillance systems for suicide attempts and self-harm. World Health Organization. 
Research, Society and Development, v. 10, n. 7, e9710715788, 2021

(CC BY 4.0) | ISSN 2525-3409 | DOI: http://dx.doi.org/10.33448/rsd-v10i7.15788

WHO. (2019). Suicide. In (Vol. 2020).

Winicov, N. (2019). A systematic review of behavioral health interventions for suicidal and self-harming individuals in prisons and jails. Heliyon, 5, e02379. 